\title{
TRADYCJE BADAŃ HISTORIOGRAFICZNYCH NA UNIWERSYTECIE ZIELONOGÓRSKIM
}

\section{Dariusz DOLAŃSKI}

\section{ABSTRACT}

\section{Traditionals of historiographical research at the Zielona Góra University}

The historical research community in Zielona Góra was took shape after 1945. In the town newly incorporated into Poland, historians were the first scholars to undertake research activities. It was in 1971 that an academic institution, able to educate historians, was established. The early studies on the history of historiography in Zielona Góra are associated with Kazimierz Bartkiewicz (1930-2002), who since the 1980s had been working on the Polish historiography of the Enlightenment and the problems of the Oder region in Polish historiography. He was succeeded in this field by Dariusz Dolański, who studied the image of the West and the East in the Polish historiography of the 18th century. The most important works of both scholars were inspired by the historical research community of Adam Mickiewicz University in Poznań, especially by Prof. Jerzy Topolski. A milestone in the development of historiographic studies at the University of Zielona Góra was the establishment of the Department of History of Science and Culture in 2007. The research projects in the Department have produced so far a number of MA theses devoted to the history of historiography and historical memory, as well as Anna Janczys' PhD dissertation devoted to Joachim Lelewel. Moreover, as a part of the research carried out in the Department, Andrzej Gillmeister published a monograph on Tadeusz Zieliński. Gillmeister's main research interests are ancient history and the $20^{\text {th }}$ century historiography of the former.

\section{KEYWORDS:}

historiographical research, Poland, University of Zielona Góra, $17^{\text {th }}$ century, $19^{\text {th }}$ century, $20^{\text {th }}$ century 
Zielonogórskie środowisko historyczne ukształtowało się po 1945 roku. W przejętym przez Polskę mieście to właśnie historycy byli pierwszymi, którzy podjęli działalność badawczą. Za momenty przełomowe w rozwoju tego środowiska należy uznać założenie w 1954 roku oddziału Polskiego Towarzystwa Historycznego, otwarcie w 1958 roku Stacji Naukowej PTH, powołanie w 1964 roku Lubuskiego Towarzystwa Naukowego i utworzenie w 1971 roku Wyższej Szkoły Nauczycielskiej, od 1973 roku Wyższej Szkoły Pedagogicznej, która zaczęła kształcić na kierunku historia'. W 1964 roku absolwent Wyższej Szkoły Pedagogicznej w Krakowie, regionalny działacz społeczno-kulturalny i nauczyciel z Kożuchowa Hieronim Szczegóła uzyskał w swojej macierzystej uczelni stopień doktora. Był pierwszą osobą w regionie zielonogórskim ze stopniem naukowym, niebawem też stał się jednym z organizatorów pierwszej w Zielonej Górze wyższej uczelni - Wyższej Szkoły Inżynierskiej, a w 1971 organizatorem i pierwszym rektorem $\mathrm{WSN}^{2}$.

$\mathrm{Z}$ tego samego rocznika studiów i z tego samego seminarium wywodził się nauczyciel i dyrektor Instytutu Kształcenia Nauczycieli i Badań Oświatowych w Zielonej Górze Kazimierz Bartkiewicz (1930-2002)33, który w 1970 roku uzyskał stopień doktora, a w 1975 roku rozpoczął pracę w zielonogórskiej WSP. Już wcześniej K. Bartkiewicz związany był z Lubuskim Towarzystwem Naukowym. Współpracowało ono ściśle z ośrodkiem poznańskim, który miał także istotny wpływ na kształtowanie się zielonogórskiego środowiska historycznego, koncentrującego się w latach 70. XX wieku głównie wokół WSP. Tą drogą Kazimierz Bartkiewicz nawiązał kontakty z prof. Jerzym Topolskim, który był częstym gościem w Zielonej Górze. Zapewne to właśnie J. Topolski zainspirował K. Bartkiewicza, by zająć się badaniami nad historiografią; nie bez znaczenia było pewnie także i to, że K. Bartkiewicz prowadził ze studentami kurs metodologii historii. To właśnie na seminarium prof. J. Topolskiego powstała koncepcja najważniejszej chyba historiograficznej książki K. Bartkiewicza: Obraz dziejów ojczystych $w$ świadomości historycznej $w$ Polsce doby oświecenia ${ }^{4}$. Wpływ na ostateczny kształt publikacji mieli także jej recenzenci wydawniczy, profesorowie Andrzej Feliks Grabski i Jerzy Wojtowicz. Z jej tytułu i wstępnych założeń wynika,

Por.: J. Kuczer, Polskie Towarzystwo Historyczne Oddział w Zielonej Górze (1954-2004), w: 50 lat Polskiego Towarzystwa Historycznego w Zielonej Górze, red. D. Dolański, Zielona Góra 2005; D. Dolański, Zielonogórska droga do uniwersytetu, wyd. 2 popr. i uzup., Zielona Góra 2012.

2 D. Dolański, Hieronim Szczegóta. Szkic biograficzny, w: Profesor Hieronim Szczegóta. W 80. rocznicę urodzin, red. D. Dolański, Zielona Góra 2011.

3 T. Jaworski, W70. Rocznicę urodzin Profesora Kazimierza Bartkiewicza, w: K. Bartkiewicz, Myśl historyczna $w$ Polsce Nowożytnej a dzieje ziem nadodrzańskich. Zbiór studiów, wyb. T. Jaworski, Zielona Góra 2001, s. 5-7; D. Dolański, Zielonogórska..., s. 281-28.

4 K. Bartkiewicz, Obraz dziejów ojczystych w świadomości historycznej w Polsce doby oświecenia, Poznań 1979. 
że analizuje ona wyobrażenia o dziejach ojczystych jako ważny składnik tzw. świadomości historycznej poprzez pryzmat „oświeceniowego klucza”, swoistego kanonu wspólnych elementów świadomościowych, będących rezultatem ustosunkowania się do tradycji sarmackiej jak i nowości europejskiego oświecenia. Właściwa analiza poprzedzona została wstępem, w którym wskazano na relacje między wyobrażeniami o przeszłości a świadomością historyczną, pierwszy zaś rozdział został poświęcony zdefiniowaniu owego „oświeceniowego klucza”. Kolejne części opracowania to już analiza wyobrażeń o przeszłości przez jego pryzmat od czasów mitycznych, przez epokę piastowską, jagiellońską, królów elekcyjnych po oświeceniową współczesność z wizją przyszłości Polski włącznie. Jeden z rozdziałów traktuje też o świadomości dziejowego miejsca Polski w świecie.

Autor wyznaczył sobie niewątpliwie ambitny cel, analizą objął niezwykle bogaty zasób źródeł od historiograficznych, przez publicystykę, historyzującą literaturę piękną, inwentarze biblioteczne, pamiętniki, korespondencję, diariusze i mowy sejmowe, kazania, słowniki po ikonografię. Praca charakteryzowała się niewątpliwe nowatorskim ujęciem metodologicznym, wzbudzając krytyczną dyskusję w środowisku historyków historiografii i badaczy oświecenia ${ }^{5}$. Jerzy Maternicki wskazywal jednak po latach, że pośród prac poświęconych historiografii i kulturze historycznej polskiego oświecenia „największe znaczenie wydaje się mieć książka Kazimierza Bartkiewicza”.

W latach 80. zainteresowania badawcze K. Bartkiewicza skierowały się ku refleksji o dawnej historiografii polskiej dotyczącej Ziem Odzyskanych. W 1985 roku wraz z Joachimem Benyskiewiczem (1936-2011) opublikował wybór polskich historiograficznych źródeł dotyczących ziem nadodrzańskich ${ }^{7}$. Książka ta dawała nie tylko przegląd wypowiedzi polskich kronikarzy i historyków o zachodnich obszarach ukształtowanej po 1945 roku Polski, ale też ich chronologiczną systematykę. I tak autorzy wyróżnili sześć etapów: 1) XIII-XV wiek, który cechowała „piastowska” orientacja trwania przy Odrze i Bałtyku; 2) XVI i pierwsze dwa dziesięciolecia XVII wieku, charakteryzujący się ścieraniem orientacji zachodniej (piastowskiej) z coraz wyraźniej występującą wschodnią (jagiellońską); 3) od lat 30. XVII wieku do pierwszej ćwierci XVIII stulecia, okres wyraźnego osłabienia orientacji zachodniej i zapatrzenia na wschód; 4) oświecenie (1733-1815), czas zwrotu orientacyjnego

5 F. Bronowski, „Kwartalnik Historii Nauki i Techniki”, 1985:3/4, s. 707-710 ; I. Łossowska, „Wiek Oświecenia” 1984, nr 4, s. 183-185.

6 J. Maternicki, Polskie badania w zakresie historii historiografii (1936- 1986), „Kwartalnik Historyczny”, 1987:1, s. 337.

7 Od Dlugosza do Parczewskiego Z dziejów myśli o polskich ziemiach zachodnich, wybór i oprac. K. Bartkiewicz, J. Benyskiewicz, Zielona Góra 1985. 
i odzyskiwania miejsca utraconego przez orientację zachodnią; 5) 1815-1863 czas zbiegania się obu nurtów i 6) 1864-1918 - ponownego ich ścierania. Autorzy podjęli też próbę charakterystyki późniejszych postaw wobec ziem nadodrzańskich, które jednak ze współczesnego punktu widzenia wymagałyby znaczących przewartościowań.

Następna publikacja K. Bartkiewicza była kontynuacją obu nurtów zainteresowań badawczych odnoszących się zarówno do XVIII wieku, jak i problematyki ziem zachodnich. W 1987 roku ukazała się monografia pt. Ziemie Zachodnie w myśli historyczno-politycznej polskiego oświecenia ${ }^{8}$. Problematyką nawiązywała ona wyraźnie do wcześniejszych publikacji, a pod względem metodologicznym i źródłowym stanowiła kontynuację monografii o obrazie dziejów ojczystych. Punktem wyjścia zawartych w niej rozważań była, wskazywana już wyżej teza, że w okresie oświecenia następowała istotna przemiana $\mathrm{w}$ polskiej orientacji polityczno-terytorialnej polegająca na schodzeniu z tzw. jagiellońskiego, a właściwie sarmackiego szlaku wschodniego na piastowski szlak zachodni. Teza ta - jak wskazywano wówczas na łamach „Nowych Książek" - choć nie nowa, znalazła w pracy K. Bartkiewicza pewien nowy wymiar9 . Także i przy okazji tej książki autor wskazywał na inspiracje ze strony J. Topolskiego oraz J. F. Grabskiego i J. Wojtowicza.

W końcu w 2001 roku z okazji 70. rocznicy urodzin Profesora ukazał się zbiór jego piętnastu rozproszonych po różnych wydawnictwach studiów z lat 1980-2010, wśród których znalazły się najważniejsze teksty historiograficzne, m.in. Oświeceniowe spory i dociekania wokót początków narodu polskiego; Wyobraźnia i historia w polskim oświeceniu; Osiemnastowieczne wojny śląskie w opiniach przedstawicieli polskiego oświecenia, a także wystąpienia z dwóch zorganizowanych z jego inicjatywy historiograficznych sesji naukowych.

W 1986 roku z okazji 200. urodzin Joachima Lelewela odbyła się w dawnym Pałacu Talleyrandów w Żaganiu konferencja naukowa „Joachim Lelewel - człowiek i dzieło. W 200-lecie urodzin" w konferencji wzięli udział m.in. A. F. Grabski, J. Topolski, Andrzej Wierzbicki, Józef Szymański. Dwa lata później ukazał się pokonferencyjny tom zawierający najważniejsze wystąpienia oraz omówienie dyskusji11. Podobne spotkanie miało miejsce w 1997 roku, tym razem dla uczenia, przypadającej rok wcześniej, dwusetnej rocznicy śmierci Adama Naruszewicza. Wówczas z udziałem m.in. J. Topolskiego, A. F. Grabskiego, J. Maternickiego i Violetty Julkowskiej odbyła

8 K. Bartkiewicz, Ziemie nadodrzańskie w myśli historyczno-politycznej polskiego oświecenia, Warszawa - Poznań 1987.

9 R. Stobecki, „Nowe Książki”, 1989, nr 6, s. 10.

10 K. Bartkiewicz, Myśl historyczna w Polsce nowożytnej a dzieje ziem nadodrzańskich...

11 Joachim Lelewel. Człowiek i dzieło. W 200-lecie urodzin. Materiaty z ogólnopolskiej sesji naukowej, Żagań 12-14 IX 1986, red. K. Bartkiewicz, Zielona Góra 1988. 
się w podzielonogórskiej Ochli sesja zatytułowana „Adam Naruszewicz i historiografia Oświecenia”, z której materiały ukazały się drukiem w 1988 roku ${ }^{12}$. Na marginesie warto wspomnieć, że obie konferencje gościły zagranicznych prelegentów, pierwsza z Litwy, druga z Czech.

Ta konferencja była dla piszącego te słowa też pierwszą okazją do bliższego poznania polskiego środowiska historyków historiografii, a zawarta wówczas znajomość z V. Julkowską owocuje do dzisiaj. W owym czasie byłem już po niedawno obronionym doktoracie, którego recenzentami byli J. Topolski i K. Bartkiewicz, i poszukiwałem nowego pola badawczego. Właśnie w wyniku inspiracji J. Topolskiego K. Bartkiewicz zaproponował zajęcie się historiografią czasów saskich i obaj profesorowie wskazali na problem obrazu Zachodu. Żaden z nich nie doczekał publikacji książki, ale prof. Bartkiewicz niemal do końca wspomagał mnie w prowadzonych badaniach. W efekcie powstała monografia Zachód w polskiej myśli historycznej czasów saskich ${ }^{13}$. Podstawowym pytaniem stawianym w pracy był stosunek polskiej historiografii czasów saskich do Zachodu oraz stopień jego oddziaływania na jej kształt rozpatrywany na trzech płaszczyznach. Pierwsza o charakterze bio-bilbiograficznym dotyczyła bezpośrednich związków środowiska uczonych polskich z Europą zachodnią oraz zakresu zainteresowania historią i geografią tego obszaru. Druga płaszczyzna rozważań to określenie stopnia nowoczesności historiografii polskiej na tle zachodnioeuropejskim, trzecia zaś dotyczyła poziomu wydarzeniowego, związanego z wiedzą o konkretnych wydarzeniach dziejowych i stopniu ich zmitologizowania. Rozważania te ściśle powiązane były z problemem tzw. świadomości historycznej, która rozumiana tu była jako pewien zespół dynamicznych i subiektywnych modeli rzeczywistości społeczno-historycznej obejmujących wiedzę i wartości oraz związane z nimi normy zachowań. Praca spotkała się z wysoką oceną recenzentów wydawniczych. A. Wierzbicki pisał, że wkroczyła ona $\mathrm{w}$ regiony dotychczas zaniedbywane i rozprawa przynosi wiele nowego, będąc nie tylko monografią z zakresu „czystej” historii historiografii, ale dając dodatkowo oryginalne studium z dziejów kształtowania się polskiego poczucia europejskości, a J. Maternicki konstatował, że jest to pierwsza udana próba historiograficznego opracowania okresu saskiego. Wydaje się też, że włączyła ona do historiograficznych analiz

\footnotetext{
12 Adam Naruszewicz i historiografia Oświecenia, red. K. Bartkiewicz, Zielona Góra 1988.

13 D. Dolański, Zachód w polskiej myśli historycznej czasów saskich. Nurt sarmacko-teleologiczny, Zielona Góra 2002.
} 
grupę zapomnianych autorów sarmackiego nurtu historiografii, stając się inspiracją dla młodych badaczy ${ }^{14}$.

Swego rodzaju kontynuacją tych rozważań była następna monografia pt. Trzy cesarstwa ${ }^{15}$, której celem była odpowiedź na pytanie o stosunek Polaków do sąsiadów w XVIII wieku. Nie chodziło tu jednak o działania i reakcje polityczne na zmiany w międzynarodowym położeniu Rzeczpospolitej, ale o próbę przedstawienia wiedzy o przeszłości i teraźniejszości w konfrontacji z wyobrażeniami w kontekście zmian geopolitycznych, ale także i przemian związanych z przenikaniem i adaptacją idei oświecenia. Tak przedstawiony cel wprowadzał te badania w obszar historii mentalności, sytuując ją w kontekście historii historiografii, badań nad stereotypami i sposobu ich funkcjonowania w kulturze oraz imagologią. Problematyka książki koncentruje się więc na interpretacji praw do używania tytułu cesarskiego, obrazu historycznych stosunków Polski z poszczególnymi sąsiadami, ocenie współczesności w kontekście przemian XVIII wieku i stereotypów narodowych.

Niejako przy okazji, jako tło dla zasadniczych rozważań w przypadku obu tytułów pojawiły się problemy przemian intelektualnych w Polsce XVIII wieku i transferu wiedzy. Spotkały się one ze sporym zainteresowaniem za granicą, głównie w Niemczech ${ }^{16}$.

Ważnym momentem dla rozwoju badań historiograficznych na Uniwersytecie Zielonogórskim było powołanie w 2007 roku Zakładu Historii Nauki i Kultury. W ramach prowadzonych w nim projektów powstało kilka prac magisterskich poświęconych historii historiografii i pamięci historycznej oraz poświęcona Joachimowi Lelewelowi praca doktorska Anny Janczys ${ }^{17}$. Rozprawa zawierała analizę prac Lelewela z zakresu teorii historii a także prac historycznych poświęconych historii Polski i powszechnej pod kątem poszukiwania związków z ideami oświecenia.

14 J. Żukowska, Jan Poszakowski - Historyk z czasów saskich. Rozprawa doktorska napisana pod kierunkiem M. Drozdowskiego, Wydział Filologiczno-Historyczny Akademii Pomorskiej w Słupsku; P. S. Ślusarczyk, Między traktatem historycznym a publicystyką. Studium o „Trwałości szczęśliwej królestw” Szymona Majchrowicza. Rozprawa doktorska napisana pod kierunkiem R. Krzywego, Wydział Polonistyki Uniwersytetu Warszawskiego, 2013. J. Żukowska opublikowała także omówienie pracy D. Dolańskiego („Słupskie Studia Historyczne 11:2004).

15 D. Dolański, Trzy cesarstwa. Wiedza i wyobrażenia o Niemczech, Turcji i Rosji w Polsce XVIII wieku, Zielona Góra 2013.

16 D. Dolański, Western European inspirations in the Polish historiography in the first half od the 18th century, w: Aufklärung und Kulturtransfer in Mittel- und Osteuropa, Hrsg. A. Pufelska, I. M. D’Aprile, Hannover 2009; Idem, Monarchen und Historiographen in Polen von 16. bis zum 18. Jahrhundert, w: Historiographie an europäischen Höfen (16.-18. Jahrhundert), Berlin 2009, [„Zeitschrift für historische Forschung“, Bd. 43]; Idem, Est-West-imagine in the Polish first half of 18th century historiography, w: Notions of the Self. The search for identity in the East-Central Europe in the $18^{\text {th }}$ century, eds. D. Dolański, A. Pufelska, Zielona Góra - Potsdam 2012; Idem, Das Russlandbild in Polen - eine Rezeption auf westlichen Umwegen, w: Konstruierte (Fremd-?)Bilder. Das östliche Europa im Diskurs des 18. Jahrhunderts, Hrsg. Ch. Augustynowicz, A. Pufelska, München 2016.

17 A. Janczys, Inspiracje oświeceniowe inspiracje w pisarstwie historycznym Joachima Lelewela. Praca doktorska napisana pod kierunkiem D. Dolańskiego, Wydział Humanistyczny Uniwersytetu Zielonogórskiego, 2014. 
W ramach prac prowadzonych w zakładzie powstała także monografia Andrzeja Gillmeistra poświęcona Tadeuszowi Zielińskiemu ${ }^{18}$. A. Gillmeister jest absolwentem historii na Uniwersytecie Mikołaja Kopernika w Toruniu i uczniem prof. Danuty Musiał oraz ukończył studia doktoranckie na Uniwersytecie Zielonogórskim. Jego główny obszar zainteresowań to historia starożytna i poświęcona jej historiografia XX wieku ${ }^{19}$. Punktem wyjścia do podejmowanych przez niego rozważań dotyczących dorobku T. Zielińskiego była teza, że poglądy polskiego uczonego na temat przemian religijnych u schyłku republiki rzymskiej były w dużej mierze oryginalne na tle współczesnej mu historiografii i spotykały się ze znaczącym oddźwiękiem. Analiza A. Gillmeistra skupia się na dwóch wiodących tematów, analizowanych w kontekście myśli Georga Wissowy i Franza Cumonta: po pierwsze rekonstrukcji poglądów uczonego na religię rzymską, po drugie przedstawienia zagadnienia „sybillińskiego mesjanizmu”. Tak więc A. Gillmeister podją się określania stopnia paradygmatyczności koncepcji Zielińskiego, w rozumieniu proponowanym przez Thomasa Kuhna, w celu określenia nie tylko oryginalności tej koncepcji, ale i jej trwałości. D. Musiał w recenzji wydawniczej wskazywała, że największą zaletą opracowania jest wskazanie źródeł oryginalności religioznawczych koncepcji Zielińskiego-intelektualisty i rekonstrukcja warsztatu badawczego Zielińskiego-historyka religii rzymskiej. V. Julkowska oceniając dorobek naukowy A. Gillmeistra, w którym wzmiankowana praca było podstawą przewodu habilitacyjnego, zwróciła uwagę, że zarówno w kontekście analityczno-interpretacyjnym, jak i metodologiczno-koncepcyjnym można ją ocenić jako pionierską, a zastosowaną strategię badawczą za nowatorską.

Tak więc tradycje badań historiograficznych w Zielonej Górze mają już około 40 lat, choć reprezentujące je środowisko nie jest liczne, początkowo reprezentowane tylko przez K. Bartkiewicza, dziś przez dwie osoby w grupie samodzielnych pracowników nauki, wydaje się, że ich dorobek jest zauważalny nie tylko w Polsce, ale też za granicą, a zapewnione następstwo pokoleniowe daje szansę dalszego ich rozwoju.

18 A. Gillmeister, Między historiografią a historiozofią. Tadeusza Zielińskiego wizja religii rzymskiej, Kraków 2015.

19 A. Gillmeister, Kontrowersje wokót książki „Hellenizm a judaizm” Tadeusza Zielińskiego. Polemiki chrześcijańskie „Scripta Biblica et Orientalia” 2011:3; D. Musiał, A. Gillmeister, Badania nad religia rzymska w Polsce, w: Oblicza starożytności. Z badań nad historią starożytna w Polsce, red. M. Wolny, Olsztyn 2012; A. Gillmeister, The Point of View. Tadeusz Zieliński on Ancient Religions, Warszawa 2013. 